\title{
Emergence of Loneliness through Degradation of Our Physical Environment
}

\author{
Shelly Bhagat ${ }^{1 *}$
}

\section{ABSTRACT}

Our Environment is growing and enriching us on the cost of its own well being. The matter of concern of environmental psychology is so much important in today's era to save the future psychological/mental as well as physical health. The core idea of learning the cause of loneliness due to the physical changes of environment can hence change the foresightedness for the field of psychology. The few basic and the important factors which are helpful in understanding the overall health of the environment and its contribution in the loneliness of human beings are discussed in this study.

Keywords: Loneliness, Environment, Psychological well being.

The condition of our planet is such that it is showing signs of loneliness, as if it is totally forgotten by its intelligent human beings. In this era, the concept is not only about talking to the mere health effects of loneliness on human beings, rather the health of the planet which indeed is suffering acute loneliness. We cannot here challenge the nature as we ourselves have evolved from it, and despite of this fact we kept ignoring it.

Why, this concept of loneliness is being talked about in relation to our dear mother "The Earth" is the pro idea of knowing what clearly the planet is showing us except behaving as ones as if we are deeply unaware of the devastating effects the land, oceans, and the so called sky is facing because of our stupidness. What is loneliness? And How can we know that our Earth is lonely or not? The answers to these questions are being laid down by the facts and findings of the earlier research and history of loneliness, which is in it again, is limited.

Loneliness is that state of isolation in which the sadness prevail the most because of not finding the appropriate company. Earth is lonely? But, how? Our mother earth gave us a ground to play and live happily, it gave us few props which we can use effectively for our excellent performance, and yes we used it in fact we overused everything provided to us, without thinking

\footnotetext{
${ }^{1}$ Research Scholar, Department of Psychology, Panjab University, Chandigarh, India *Responding Author

(C) 2016 I S Bhagat; licensee IJIP. This is an Open Access Research distributed under the terms of the Creative Commons Attribution License (http://creativecommons.org/licenses/by/2.0), which permits unrestricted use, distribution, and reproduction in any Medium, provided the original work is properly cited.
} 
twice and that too for the finest excellent performance by us. The Earth ignored many of our tantrums and silently with deep tensions it kept running with the changes its children are imposing on it. And know being the developed planet in itself it has become the lonelier even than that of the other planets which do not have an existence of life, yet they shine bright and contended.

Well, as mentioned in the previous paragraph that the mother has given us props to excel, and we though overused those props, is the real and the core reason of loneliness of our dear Mother "Earth". Earth is lonely as with the developments being made the results are hazardous of its children in the long run, not only for its intelligent children but for all the beautiful children (living and non living) she has.

The change in the environment not only encompass the physical changes but also the changes in the lifestyle of the living beings, the change in the imprint of species and the change in the foresight due to the physical changes as well. Phenotypic plasticity is another area being affected with these changes.

MAJOR ENVIRONMENTAL ISSUES AFFECTING MENTAL AS WELL AS PHYSICAL LIVES:

Pollution:

More than half of the human population knows what pollution is, but we are still not ready to face its damaging consequences. Pollution is not only limited to water, soil and noise but has extended to light, visual, point and non-point sources. Human beings and their actions are majority responsible for causing all types of pollution.

Most polluted city in the world: Delhi (India).

\section{Climate Change:}

Climate change today is less of a natural process. It is rapidly occurring due to the ill effects of human actions responsible for disturbing and harmful out comings such as global warming, greenhouse effect, urban heat, coal industry etc. It is not only changing the overall weather scenario, but has larger and harmful effects, foe example, melting of polar regions, occurrence of new diseases and permanent inhibition in growth of certain plants essential for human survival.

\section{Global Warming:}

It is yet another environmental issue which is increase in earth's temperature due to effect of greenhouse gases called carbon dioxide, methane, water vapor and other gases. According to Environmental Protection Agency (EPA) reports, the earth's temperature has increased by 0.8 degree Celsius over the past century. 
GLOBAL WARMING CAN HAVE LONG LASTING EFFECTS WHICH CAN RESULT

IN MELTING OF GLACIERS, CLIMATE CHANGE, DROUGHTS, DISEASES AND INCREASE IN HURRICANES FREQUENCY.

\section{Overpopulation:}

This is a never-ending human tragedy which is responsible for causing all types of environmental issues.

\section{Acid Rain:}

It simply means rain that is acidic in nature due to the presence of certain pollutants in the atmosphere. These pollutants come in the atmosphere due to car or industry processes. It can occur in form of rain, snow, fog or dry material that settles to earth. Acid rain has devastating effects on aquatic life, forests, public health and architecture and buildings.

\section{Ozone Layer depletion:}

Ozone layer id a layer of gas that sits $25-30 \mathrm{~km}$ above earth's surface. It mainly contains ozone which is a naturally occurring molecule containing three oxygen atoms. This layer is present in the stratosphere and prevents too many harmful UV (Ultra Violet) radiations from entering the earth. This layer is capable of absorbing 97-99\% of the harmful ultraviolet radiations that are emitted by sun. The main cause of depletion of ozone layer is determined as excessive release of chlorine and bromine from man-made compounds such as; Chloroflurocarbons (CFCs), Helons, Methyl chloroform, Carbon tetrachloride, Hydro-chloroflurocarbons, Hydrobromofluorocarbons and methyl bromide, are found to have direct impact on the depletion of the ozone layer.

\section{Ocean Acidification:}

It is a direct impact of excessive production of CO2. The ocean acidity has increased by the last 250 years but by 2100, it may shoot up $150 \%$. The main impact is on shelfish and plankton in the same way as human osteoporosis.

\section{Urban Sprawl:}

Urban sprawl refers to migration of population from high density urban areas to low density rural areas which results in spreading of city over more and more rural land. Urban sprawl results in land degradation, increased traffic, environmental issues and health issues.(http://www.conserveenergy-future.com/15-current-environmental-problems.php)

How pollution effect mental health? Many findings suggest that pollution effects brain structure as well as the working of neurological system. Among the various psychological and neurological effects found by studies described in the APA report (http://grist.org/climateenergy/air-pollution-can-wreck-your-mental-health-too/):

- "Older women who had been exposed to high levels of [particulate matter] experienced greater cognitive decline compared with other women their age.” 
- "Kids exposed to greater levels of black carbon (soot) scored worse on tests of memory and verbal and nonverbal."

- "Children who had been exposed to higher levels of urban air pollutants known as polycyclic aromatic hydrocarbons while in utero were more likely to experience attention problems and symptoms of anxiety and depression.”

"Pollutant-exposed mice showed signs of the rodent equivalent of depression. They demonstrated depressive-like symptoms such as giving up swimming more quickly in a forced swim test and stop sipping sugar water that they normally find attractive. Both behaviors can be reversed with antidepressants.”

Loneliness as on ontological phenomenon is the "universal quality of human existence, just as common and as frequently experienced as happiness, hunger or sadness" (Dolęga Z. 2003, p. 9). Loneliness in social and psychological context is taken as a deteriorated self, personal well-being and is also commonly related to very low level of satisfaction with one's own life. The environmental issues causing psychological issues are not less than the tsunamis in neurological system. The cognitive deficit perspective proposes that loneliness is a deficit between actual and desired quantity/quality of social engagement (Peplau et al. 1982). This social engagement with distressed environment causes alot more than a psychological imbalance of human beings.Many studies demonstrate the deleterious influence of urbanization on human behavior (Baum et al. 1978). Recently attempts have been made to relate environmental preferences to personality characteristics, race and national character (Hall 1976; Berry 1976).

\section{SUMMARY}

The physical environmental changes causing degradation in the psychological well being is the idea of this study to be focused upon. We have discussed few factors which are disturbing the environment and hence are responsible for the human psychological health causing loneliness, depression and other physical as well as mental disorders in human beings. We are hence not focusing upon the usage of the provided natural resources in the desired limits which will not negatively affect us. This above study is hence providing an important source of research for the future findings in this area of environmental psychology affecting human psychology in reality.

\section{REFERENCES}

Baum A., Singer J E and Valins S (Eds) 1978 Advances in Environmental Psychology: Vol I The Urban Environment: John Wiley \& Sons, Inc.; New York

Berry J W 1976 Ecological and cultural factors in spatial perceptual development; In: Environmental psychology (Eds) Proshansky H M, Ittelson W H and Rivlin L G. Holt, Rinehart and Winston, New York.

Dołęga Z. (2003) Samotność młodzieży: analiza teoretyczna I studia empiryczne, Katowice: Wydawnictwo UŚ. 
Peplau, L. A., Miceli, M. \& Morash, B. (1982). Loneliness and selfevaluation. In L. A. Peplau \& D. Perlman (Eds.), Loneliness: A Sourcebook of Current Theory, Research, and Therapy (pp. 131-151). New York: John Wiley.

\section{Websites:}

http://www.conserve-energy-future.com/15-current-environmental-problems.php http://grist.org/climate-energy/air-pollution-can-wreck-your-mental-health-too/ 